\title{
Transport of IGF-I across epithelial cell monolayers
}

\author{
S E P Bastian, P E Walton, F J Ballard and D A Belford \\ Cooperative Research Centre for Tissue Growth and Repair, CSIRO, Human Nutrition, PO Box 10041, Adelaide BC, Australia, 5000 \\ (Requests for offprints should be addressed to S E P Bastian)
}

\begin{abstract}
Epithelial cells line the lumens of organs including the gastrointestinal tract, kidney tubules and respiratory airways, where they regulate the transport of electrolytes and the movement of macromolecules. The current study aimed to investigate the transport of IGF-I across epithelial cell barriers. Epithelial cell lines derived from gut (IEC-6), kidney $(\mathrm{MDBK})$ and lung $(\mathrm{Mv} 1 \mathrm{Lu})$ were shown to possess high-affinity, functional receptors for IGF-I and formed tight junctions in monolayer culture. To investigate the transport of IGF-I, the three cell lines were grown on microporous filters in a bi-chamber system. In comparison with filters without cells, IEC-6 and Mv1Lu epithelial cell monolayers restricted the passage of ${ }^{125}$ I-IGF-I and
\end{abstract}

$\left[{ }^{3} \mathrm{H}\right]$ inulin, whereas the MDBK cells virtually occluded any passage of these molecules. Transport of ${ }^{125}$ I-IGF-I across the epithelial cell monolayers was significantly less than that of $\left[{ }^{3} \mathrm{H}\right]$ inulin, suggesting that the binding of ${ }^{125}$ I-IGF-I to high-affinity IGF receptors or IGF-binding proteins retarded its transport. Moreover, ${ }^{125} \mathrm{I}-\mathrm{IGF}-\mathrm{I}$ transport was not inhibited by the presence of excess unlabelled IGF-I. Our findings provide evidence for the restricted diffusion of intact, free IGF-I across gut, kidney and lung epithelial cell monolayers via a paracellular or low-affinity transcellular pathway.

Journal of Endocrinology (1999) 162, 361-369

\section{Introduction}

Transport of macromolecules across epithelial surfaces occurs via either active transcellular or passive paracellular pathways. Proteins such as horseradish peroxidase, insulin, immunoglobulin-G and beta-lactoglobulin have been shown to be actively transported across the epithelium lining the small intestine in membrane-bound vesicles after binding to cell-surface receptors or binding sites (Walker et al. 1972, Wheeler et al. 1993, Bendayan et al. 1994, Jochims et al. 1994, Kiliaan et al. 1996). In contrast, a component of the transport of horseradish peroxidase and BSA across epithelial monolayers occurs by passive intercellular diffusion (Rhodes \& Karnovsky 1971, Warshaw et al. 1974, Kiliaan et al. 1996). Several growth factors including insulin, epidermal growth factor, nerve growth factor and insulin-like growth factor-I (IGF-I) are taken up by the gut in an active form (Kelly 1960, Aloe et al. 1982, Thornburg et al. 1984, Philipps et al. 1990).

Significant attention has been focused on the transport and possible role of enteral IGF-I. IGF-I is a potent promoter of growth, metabolism and differentiation of numerous cell types including epithelial cells (Corps \& Brown 1987). Administered systemically, IGF-I promotes gut growth and maturation (Read et al. 1992) and orally administered IGF-I acts locally to stimulate gut proliferation (Baumrucker et al. 1994, Burrin et al. 1996). IGFs have been detected in the milk of many species (Baxter et al. 1984, Donovan et al. 1991, Vega et al. 1991, Olanrewaju et al. 1996). Orally administered ${ }^{125}$ I-IGF-I is absorbed by the gut and appears in the circulation intact (Baumrucker et al. 1992, Vacher et al. 1995, Odle et al. 1996, Kimura et al. 1997, Xu \& Wang 1996).

To exert its mitogenic actions, IGF-I binds to the type I IGF receptor on target cell membranes (LeRoith et al. 1995). Type I IGF receptors have been identified on porcine small intestinal mucosal membrane preparations (Schober et al. 1990), on the basolateral membranes of enterocytes in piglets (Morgan et al. 1996) and the villus and crypt epithelium of the rat (Heinz Erian et al. 1991, Ryan \& Costigan 1993, Laburthe et al. 1996). Intestinal cell lines derived from rat jejunal crypts (IEC-6), as well as the rat, rabbit and human colon (Caco-2) also express IGF type I receptors (Pillion et al. 1989, Park et al. 1990, Rouyer Fessard et al. 1990, Hoeflich et al. 1994). Whether these receptors mediate the transport of IGF across epithelial monolayers is currently unknown.

In the present study we have examined the transport of ${ }^{125}$ I-IGF-I across monolayers of a rat small intestinal epithelial cell line and compared this transport with that observed across kidney- and lung-derived epithelial cell lines. We present evidence for the restricted diffusion of intact IGF-I across these epithelial cell monolayers via a paracellular or low-affinity transcellular route. 


\section{Materials and Methods}

\section{Materials}

Recombinant human (rh) IGF-I and IGF-II were purchased from GroPep Pty Ltd (Adelaide, Australia). IGF-I was iodinated with carrier-free $\mathrm{Na}^{125} \mathrm{I}$ from Amersham International (Bucks, UK), to a specific activity of $85 \mu \mathrm{Ci} / \mu \mathrm{g}$, using a modification of the chloramine $\mathrm{T}$ method (Gargosky et al. 1990). $\left[{ }^{3} \mathrm{H}\right]$ inulin $(1 \cdot 18 \mathrm{Ci} / \mathrm{mmol})$ was also obtained from Amersham and [methyl- ${ }^{3} \mathrm{H}$ ] thymidine $(20 \mathrm{Ci} / \mathrm{mmol})$ was purchased from New England Nuclear (Boston, MA, USA). Foetal bovine serum (FBS) was purchased from Cytosystems (Castle Hill, Australia). Hanks' balanced salts solution was purchased from ICN Biomedicals (Costa Mesa, CA, USA) and Dulbecco's modified Eagle's medium (DMEM) was obtained from Flow Laboratories (Irvine, Scotland). Methylene blue, BSA and Tris (tris(hydroxylmethyl) amino-methane) were from Sigma (St Louis, MO, USA). Hepes (N-(2-hydroxyethyl) piperazine-N'-(2ethanesulphonic acid)), trichloroacetic acid (TCA) and di-sodium tetraborate were all from BDH Chemicals (Victoria, Australia). All transmigration experiments were carried out using transwells $(6.5 \mathrm{~mm}$ diameter, $0 \cdot 4 \mu \mathrm{m}$ pore size) from Costar (Cambridge, MA, USA). Disuccinimidyl suberate was obtained from ICN Biochemicals Australasia Pty Ltd (Seven Hills, Australia). Protein molecular mass standards were obtained from Pharmacia (Uppsala, Sweden).

\section{Cell culture}

Madin-Darby bovine kidney (MDBK; CRL 6071), normal mink lung (Mv1Lu; CCL 64) and rat small intestinal crypt (IEC-6; CRL 1592) epithelial cell lines were all purchased from American Type Culture Collection (Rockville, MD, USA). All cells were grown in DMEM containing 10\% FBS, together with $100 \mathrm{mg}$ streptomycin, $60 \mathrm{mg}$ penicillin and $1 \mathrm{mg}$ fungizone per litre of growth medium. The cells were grown and used for experiments as monolayers at $37^{\circ} \mathrm{C}$ in $5 \% \mathrm{CO}_{2}$.

\section{Radioreceptor assays}

The procedure for this assay has been described previously (Ross et al. 1989). Briefly, epithelial cells were subcultured onto 24-place multiwell plates (Costar) and grown to confluence. The cells were washed twice and incubated for $2 \mathrm{~h}$ at $4{ }^{\circ} \mathrm{C}$ in Hepes-buffered saline (Hepes $(0 \cdot 1 \mathrm{~mol} / \mathrm{l}), \mathrm{NaCl}(0 \cdot 12 \mathrm{~mol} / \mathrm{l}), \mathrm{KCl}(5 \mathrm{mmol} / \mathrm{l}), \mathrm{MgSO}_{4}$ $7 \mathrm{H}_{2} \mathrm{O}(1 \cdot 2 \mathrm{mmol} / \mathrm{l})$ and glucose $\left.(8 \mathrm{mmol} / \mathrm{l}), \mathrm{pH} 7 \cdot 6\right)$ plus BSA $(0.5 \% \mathrm{w} / \mathrm{v})$. Cells were then incubated for $18 \mathrm{~h}$ at $4{ }^{\circ} \mathrm{C}$ in $500 \mu \mathrm{l}$ of the same buffer containing $2 \times 10^{4}$ c.p.m. ${ }^{125}$ I-IGF-I and the indicated amounts of unlabelled IGF-I. Monolayers were harvested by washing twice with
Hanks' balanced salts solution at $4{ }^{\circ} \mathrm{C}$, followed by dissolution in $\mathrm{NaOH}(0.5 \mathrm{~mol} / \mathrm{l})$ containing Triton $\mathrm{X}-100$ $(0 \cdot 1 \% \mathrm{v} / \mathrm{v})$. Bound radioactivity was determined using a gamma counter. Data were fitted to a four-parameter equation with the aid of a non-linear curve-fitting program (Tablecurve, Jandel Scientific, San Rafael, CA, USA).

\section{Affinity label cross-linking experiments}

Cross-linking was performed as described in Kasuga et al. (1981). Confluent epithelial cell monolayers in six-place multiwell plates were washed twice and incubated at $4{ }^{\circ} \mathrm{C}$ in DMEM plus BSA $(0 \cdot 1 \% \mathrm{w} / \mathrm{v})$ for $2 \mathrm{~h}$. The medium was removed and the cells incubated for a further $4 \mathrm{~h}$ with $0.5 \mu \mathrm{Ci}(5 \mathrm{ng}){ }^{125} \mathrm{I}-\mathrm{IGF}-\mathrm{I}$ in the presence or absence of a 1000 -fold excess of IGF-I or IGF-II or a $10000-$ fold excess of insulin. The medium was aspirated, the monolayers washed twice on ice with Hanks' balanced salts solution and bound IGFs chemically cross-linked by the addition of disuccinimidyl suberate $(0.5 \mathrm{mmol} / \mathrm{l})$ in DMEM for $20 \mathrm{~min}$ at $4{ }^{\circ} \mathrm{C}$. The reaction was terminated with the addition of Tris $(0.1 \mathrm{~mol} / \mathrm{l})$ containing EDTA $(1 \mathrm{mmol} / \mathrm{l})$ at $\mathrm{pH} 7 \cdot 4$. The cells were solubilised in $50 \mu \mathrm{l}$ SDS-sample buffer containing $\beta$-mercaptoethanol, heated at $95{ }^{\circ} \mathrm{C}$ for $10 \mathrm{~min}$, and subjected to SDS-PAGE through a 4\% stacking and 6\% separating acrylamide gel (Laemmli 1970). Gels were stained using Coomassie Blue R-250 and equilibrated in 10\% acetic acid and 10\% glycerol before being dried and exposed to X-ray film for 4 weeks.

\section{Measurement of DNA synthesis}

Confluent monolayers of epithelial cells grown in 24-place multiwell plates were washed twice for $30 \mathrm{~min}$ in serumfree DMEM plus BSA $(0 \cdot 1 \% \mathrm{w} / \mathrm{v})$. Each monolayer was subsequently incubated for $24 \mathrm{~h}$ in serum-free medium containing a dilution series of IGF-I. A 10\% FBS and serum-free control was also incorporated on each plate. During the last $6 \mathrm{~h}$ of this period, $1 \mu \mathrm{Ci}(5 \mathrm{nmol})$ $\left[{ }^{3} \mathrm{H}\right]$ thymidine was added to each well. Each monolayer was washed with Hanks' balanced salt solution, twice with 5\% TCA and once with water. Cells were solubilised by trituration in $\mathrm{NaOH}(0.5 \mathrm{~mol} / \mathrm{l})$ containing Triton $\mathrm{X}-100$ $(0 \cdot 1 \% \mathrm{v} / \mathrm{v})$, and incorporated $\left[{ }^{3} \mathrm{H}\right]$ thymidine quantified using a beta counter. Results are expressed as the percentage of DNA synthesis above that observed in serum-free conditions.

\section{Measurement of transepithelial electrical resistance}

Measurement of electrical resistance was undertaken to monitor the integrity of each cell monolayer used in the transport experiments. Transwells were seeded with $20 \times 10^{3}$ epithelial cells per well in DMEM plus $10 \% \mathrm{FBS}$, placed in 24-place multiwell plates containing the same 
medium and cultured for 16 days with media changes every 2 days. Transepithelial resistance measurements were made every $24 \mathrm{~h}$ using a Millicell-Electrical Resistance System (Millipore, Bedford, MA, USA). To calculate the resistance measurement of each cell monolayer, the mean resistance measurements of transwells without cells were subtracted from the monolayer measurements and corrected for the area of the transwell $\left(0.33 \mathrm{~cm}^{2}\right)$.

\section{Transmigration experiments}

Epithelial cells were grown for 6 days in transwells as described above for measurement of transepithelial resistance. Before each experiment, control transwells were routinely fixed with methanol, stained with methylene blue $(0 \cdot 1 \% \mathrm{w} / \mathrm{v})$ in di-sodium tetraborate $(0.01 \mathrm{~mol} / \mathrm{l} ; \mathrm{pH}$ 8.5 ) and visualised by light microscopy to monitor confluence. Other control transwells were fixed for $6 \mathrm{~h}$ in PBS containing paraformaldehyde $(4 \% \mathrm{w} / \mathrm{v})$, gluteraldehyde $(1 \cdot 25 \% \mathrm{v} / \mathrm{v})$ plus sucrose $(4 \% \mathrm{w} / \mathrm{v}), \mathrm{pH} 7 \cdot 2$, and processed for transmission electron microscopy (Phillips, CM 100). In addition, the integrity of every monolayer was confirmed prior to each experiment by measuring the transepithelial electrical resistance.

At time zero, the monolayers were washed with serumfree DMEM plus BSA $(0 \cdot 1 \% \mathrm{w} / \mathrm{v})$ and the transwells transferred to a new lower chamber containing $700 \mu \mathrm{l}$ fresh medium. The medium from the apical (top) chamber was removed and $150 \mu \mathrm{l}$ serum-free DMEM plus BSA $(0 \cdot 1 \% \mathrm{w} / \mathrm{v})$ containing either ${ }^{125} \mathrm{I}-\mathrm{IGF}-\mathrm{I} \quad(8 \mathrm{ng})$ or $\left.{ }^{3} \mathrm{H}\right]$ inulin $(0 \cdot 1 \mu \mathrm{g})$ were added to the apical chamber. After $5 \mathrm{~min}$ incubation at $37^{\circ} \mathrm{C}$, the basolateral (bottom) chamber was triturated, a sub-sample $(100 \mu \mathrm{l})$ taken, and the chamber immediately replenished with the same amount of fresh medium. Further sub-samples were collected at 30, 60 and $120 \mathrm{~min}$. At $120 \mathrm{~min}$, the transepithelial electrical resistance of each transwell was measured again and each transwell was fixed and stained and the confluence of the monolayer confirmed by light microscopy. Transmigrated ${ }^{125}$ I-IGF-I was measured as TCA-insoluble radioactivity. Briefly, portions of the medium from the abluminal chamber at various time points were mixed with ice-cold TCA to a final concentration of $10 \% \mathrm{TCA}$, incubated for $30 \mathrm{~min}$ at $4{ }^{\circ} \mathrm{C}$ and centrifuged at $3500 \mathrm{~g}$. The radioactivity in the TCAsoluble and TCA-insoluble portions was counted in a gamma counter. $\left[{ }^{3} \mathrm{H}\right]$ inulin samples were counted in a beta counter. Transepithelial migration of each macromolecule was expressed as a percentage of the total of intact macromolecule added to the apical chamber at time zero.

\section{Statistical analyses}

Transmigration data were analysed by one-way ANOVA with all pair-wise multiple comparisons using Student-

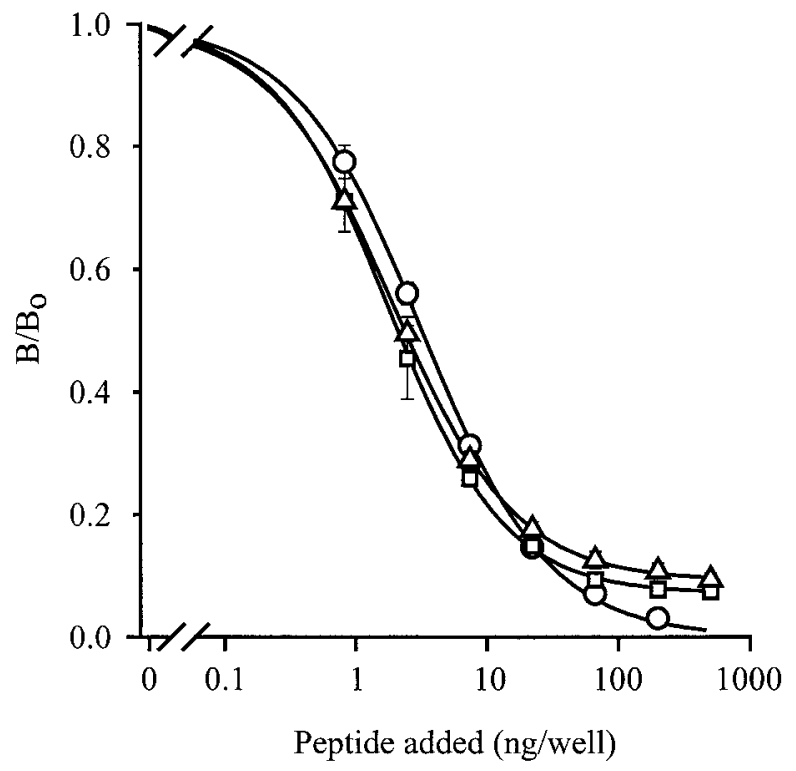

Figure 1 IGF-I radioreceptor assays. Inhibition of ${ }^{125}$ I-IGF-I binding to IEC-6 $(\bigcirc)$, Mv1Lu $(\triangle)$ and MDBK $(\square)$ cells by unlabelled IGF-I. Each point is the mean \pm S.E.M. of triplicate determinations.

Non-specific binding (amounting to $9 \cdot 4,7 \cdot 5$ and $2 \cdot 0 \%$ of total counts bound for the IEC-6, Mv1Lu and MDBK cells respectively) has been subtracted.

Newman-Keuls method. DNA synthesis data and data arising from the effects of excess unlabelled IGF-I on ${ }^{125}$ I-IGF-I transport were analysed by Student's $t$-test.

\section{Results}

\section{Competitive binding and ligand-receptor cross-linking experiments}

To confirm the presence of IGF-binding sites on epithelial cell lines, competitive-binding studies were performed on confluent cell monolayers. IEC-6 and Mv1Lu epithelial cell lines bound 3.7 and $4 \cdot 1 \%$ of the total ${ }^{125}$ I-IGF-I added to each well respectively, while the MDBK cells bound $23 \%$ of total ${ }^{125}$ I-IGF-I. The IGF-I receptor displacement curve is shown in Fig. 1. Fifty per cent of bound ${ }^{125}$ I-IGF-I were displaced by $3 \cdot 6,3 \cdot 8$ and $6 \cdot 0 \mathrm{ng} / \mathrm{ml}$ unlabelled IGF-I from Mv1Lu, IEC6 and MDBK cells respectively. To further characterise IGF-binding sites on each of the epithelial cell lines, bound ${ }^{125}$ I-IGF-I was cross-linked to cell-surface receptors in the absence or presence of saturating concentrations of unlabelled IGF-I, IGF-II or insulin. Receptor-ligand complexes identified by SDS-PAGE and autoradiography were visualised at approximately 140 and $270 \mathrm{kDa}$ for both the IEC-6 and Mv1Lu cell lines (Fig. $2 a$ and $b$ ). Both bands were sensitive to displacement when cross-linking was performed in the presence of unlabelled IGF-I, IGF-II or insulin. The 
(a)

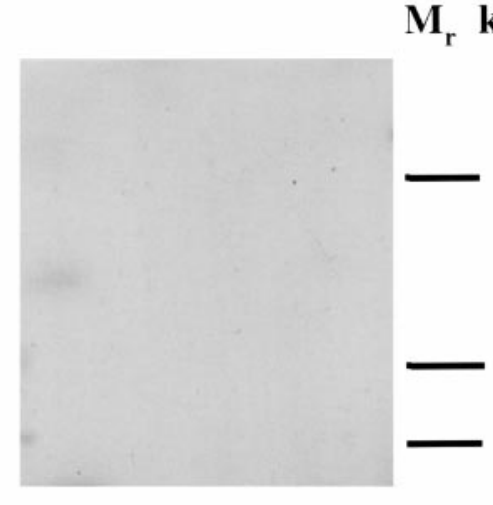

200

(b)

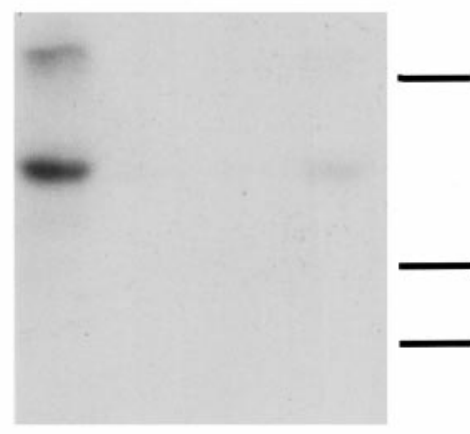

200

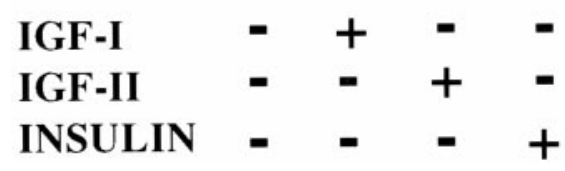

Figure 2 Autoradiograph of ${ }^{125}$ I-IGF-I cross-linked to monolayers of (a) IEC-6 and (b) Mv1Lu cells. Cross-linking was carried out in the presence $(+)$ or absence $(-)$ of IGF-I $(8 \mu \mathrm{g})$, IGF-II $(8 \mu \mathrm{g})$ or insulin $(80 \mu \mathrm{g})$. Cross-linked samples were subjected to SDS-PAGE on $6 \%$ acrylamide gels under reducing conditions and bands were visualised by exposure to X-ray film for 28 days. Positions of ${ }^{14} \mathrm{C}$-labelled molecular mass markers are indicated $\left(\times 10^{-3}\right)$.

molecular masses of these two bands are consistent with the cross-linked type I IGF receptor $\alpha$-subunit and dimers of the cross-linked $\alpha$-subunit respectively. No crosslinking of ${ }^{125} \mathrm{I}-\mathrm{IGF}-\mathrm{I}$ to MDBK cell membranes was observed. However, a band at $21 \mathrm{kDa}$ was apparent when lysates of MDBK cells incubated with ${ }^{125}$ I-IGF-I were run on a $12 \%$ polyacrylamide gel (not shown).

\section{DNA synthesis assays}

The presence of functional type I IGF receptors was further assessed using $\left[{ }^{3} \mathrm{H}\right]$ thymidine incorporation as a measure of DNA synthesis. All concentrations of IGF-I tested significantly increased $\left[{ }^{3} \mathrm{H}\right]$ thymidine incorporation into the DNA of Mv1Lu cells (Fig. 3). At the highest concentration tested $(100 \mathrm{ng} / \mathrm{ml})$, the $\mathrm{Mv} 1 \mathrm{Lu}$ cells were stimulated to increase $\left[{ }^{3} \mathrm{H}\right]$ thymidine incorporation

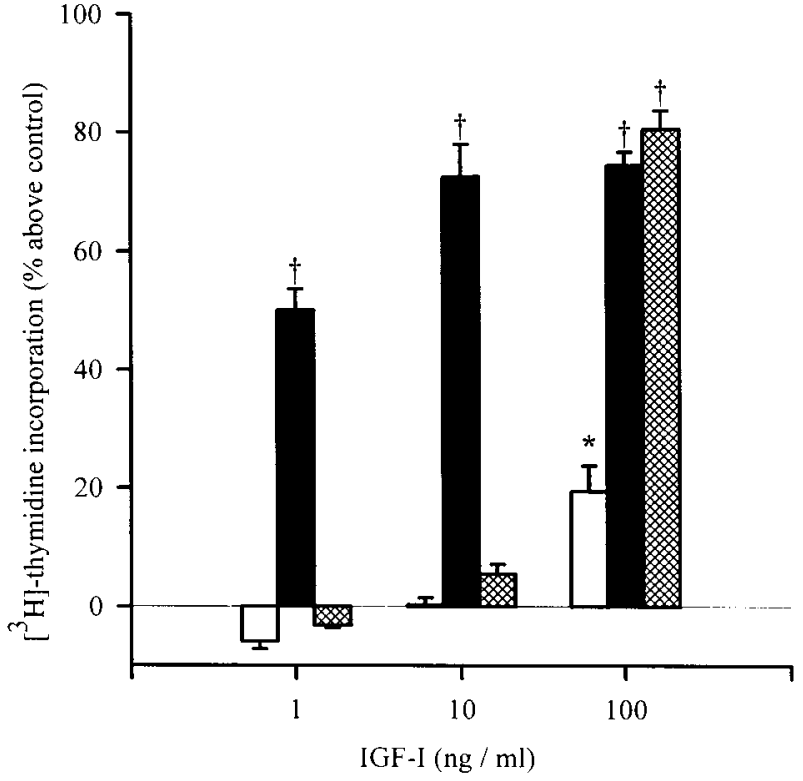

Figure $3\left[{ }^{3} \mathrm{H}\right]$ thymidine incorporation into IEC-6 (open bars), Mv1Lu (solid bars) and MDBK (hatched bars) cells treated with the indicated concentrations of IGF-I. Results are expressed as a percentage above incorporation observed under serum-free conditions (means \pm S.E.M., $n=3,{ }^{*} P<0 \cdot 05,+P<0 \cdot 01$ ).

by $74 \pm 2 \%$ (means \pm S.E.M.; $n=3$ ). The incorporation of $\left[{ }^{3} \mathrm{H}\right]$ thymidine into IEC-6 and MDBK cells was increased only after addition of $100 \mathrm{ng} / \mathrm{ml}$ IGF-I, resulting in significant increases of $20 \pm 4$ and $80 \pm 3 \%$ over serum-free conditions respectively (means \pm s.E.M.; $n=3$ ).

\section{Transmigration experiments}

The ability to grow confluent epithelial cell monolayers on transwell membranes was confirmed by transmission electron microscopy (Fig. 4). Each cell line formed a polarised monolayer of cells with a clearly defined apical membrane. Formation of tight junctions is also evident from the micrographs and they are indicated by arrows. Transepithelial electrical resistance values for all cell lines on the first 16 days after seeding at a standard concentration of $20 \times 10^{3}$ cells per transwell are shown in Fig. 5. As all monolayers were confluent at day 6 and produced consistent transepithelial electrical resistance values, all transepithelial transport studies were undertaken at this time point. The mean transepithelial electrical resistance values on day 6 post-seeding were $61 \cdot 5 \pm 7 \cdot 9,12.6 \pm 1 \cdot 7$ and $7 \cdot 9 \pm 1 \cdot 0 \Omega \mathrm{cm}^{2}$ for MDBK, IEC-6 and $\mathrm{Mv} 1 \mathrm{Lu}$ cells respectively (means \pm S.E.M; $n=5-7$ cultures). Integrity of the monolayers between experiments was routinely monitored by measuring transepithelial electrical resistance values on all cultures prior to and at the end of every transmigration experiment. These values did not significantly differ. In addition, staining and light microscopy 

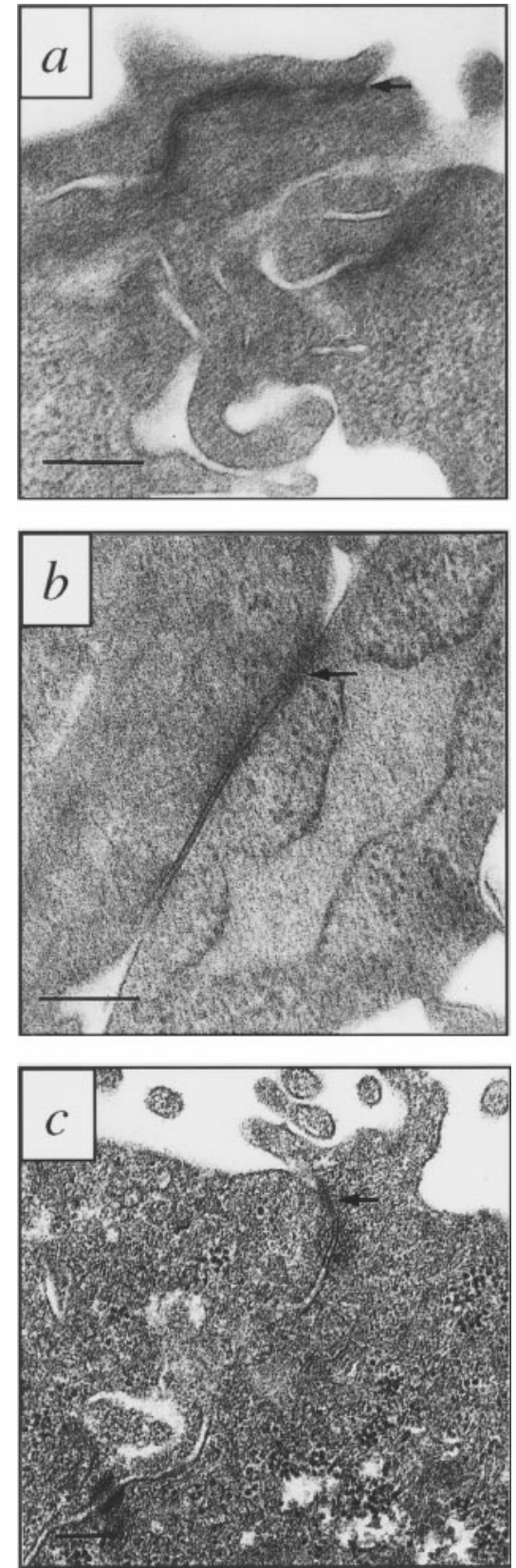

Figure 4 Transmission electron microscopy of epithelial cell monolayers grown on transwells. (a) IEC-6, (b) Mv1Lu and (c) MDBK cells were seeded on transwells in DMEM plus $10 \% \mathrm{FBS}$ and the media changed every 2 days. On day 6 post-seeding, the cells were fixed and stained for transmission electron microscopy as described in Materials and Methods. Size bars represent $1 \mu \mathrm{m}$. Tight junctions are indicated by arrows.

of all cultures confirmed the presence of confluent monolayers at the end of each experiment.

The transport of ${ }^{125}$ I-IGF-I across transwell filters alone and both ${ }^{125}$ I-IGF-I and $\left[{ }^{3} \mathrm{H}\right]$ inulin across confluent

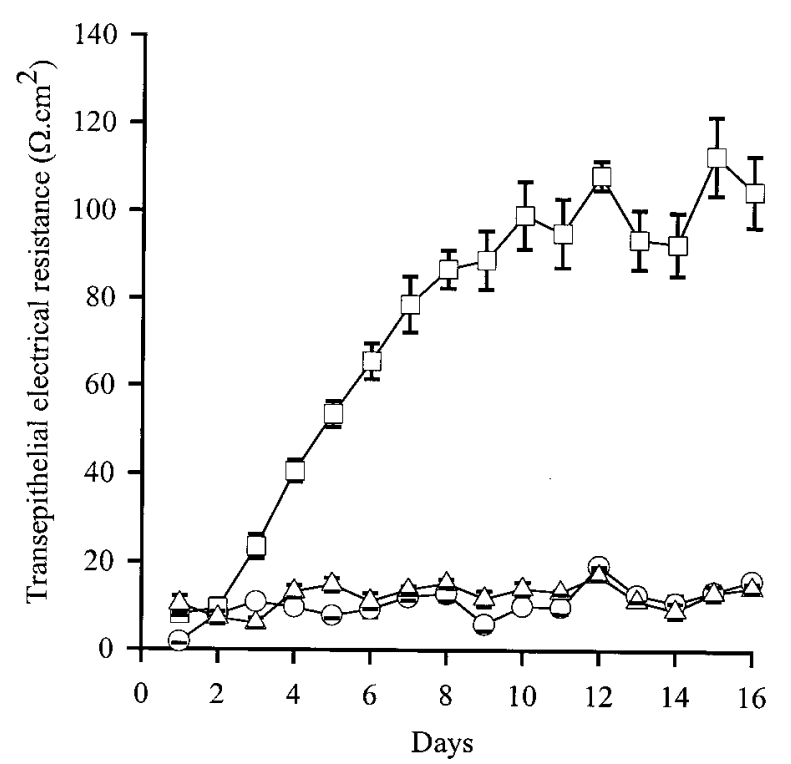

Figure 5 Transepithelial electrical resistance measurements of cell monolayers. IEC-6 $(\bigcirc)$, Mv1Lu $(\triangle)$, and MDBK $(\square)$ cells were seeded on transwells in DMEM plus $10 \%$ FBS $\left(20 \times 10^{3}\right.$ cells per well). Electrical resistance values were measured every $24 \mathrm{~h}$, each value representing the means \pm S.E.M. of three transwell cultures.

monolayers of IEC-6, MDBK and Mv1Lu cells is shown in Fig. 6. Addition of ${ }^{125} \mathrm{I}-\mathrm{IGF}-\mathrm{I}$ to the apical side of each cell monolayer resulted in a time-dependent increase in the amount of this peptide appearing intact in the basolateral chamber. At $2 \mathrm{~h}, 7 \cdot 9 \pm 0 \cdot 8,10 \cdot 8 \pm 0 \cdot 7$ and $1 \cdot 2 \pm 0 \cdot 2 \%$ of total intact ${ }^{125}$ I-IGF-I added to the apical chamber were transported by IEC-6, Mv1Lu and MDBK cell monolayers respectively (means \pm S.E.M., $\quad n=18$ cultures). The flux of ${ }^{125}$ I-IGF-I across filters without cell monolayers was significantly greater $(34 \cdot 1 \pm 0 \cdot 9 \%$, means \pm S.E.M., $n=18$ ) than that across the epithelial cells, indicating that the IEC-6 and Mv1Lu cells had greatly restricted and the MDBK cells virtually excluded the passage of ${ }^{125}$ I-IGF-I. In addition, the flux of ${ }^{125}$ I-IGF-I across the epithelial cell monolayers was significantly less than that observed for $\left[{ }^{3} \mathrm{H}\right]$ inulin.

Gel-permeation chromatography of the inulin tracer confirmed that all $\left[{ }^{3} \mathrm{H}\right]$ was present as a high molecular mass species. TCA precipitability of ${ }^{125}$ I-IGF-I immediately prior to its addition to the apical chamber was $95 \pm 0 \cdot 6 \%$ ( $n=72$ cultures). For IEC-6 and Mv1Lu cell monolayers, the majority of radioactivity appearing in the basolateral chamber was TCA precipitable. TCA precipitability gradually increased from $52 \pm 2 \%$ at $5 \mathrm{~min}$ to $63 \pm 2 \%$ by $2 \mathrm{~h}$ and from $64 \pm 4 \%$ at $5 \mathrm{~min}$ up to $76 \pm 3 \%$ by $2 \mathrm{~h}$ for the IEC-6 and Mv1Lu cells respectively (means \pm s.E.M., $n=18$ cultures), indicating the preferential movement of free ${ }^{125} \mathrm{I}$ at the earlier time points. In contrast, less than $30 \%$ of radioactivity appeared as 


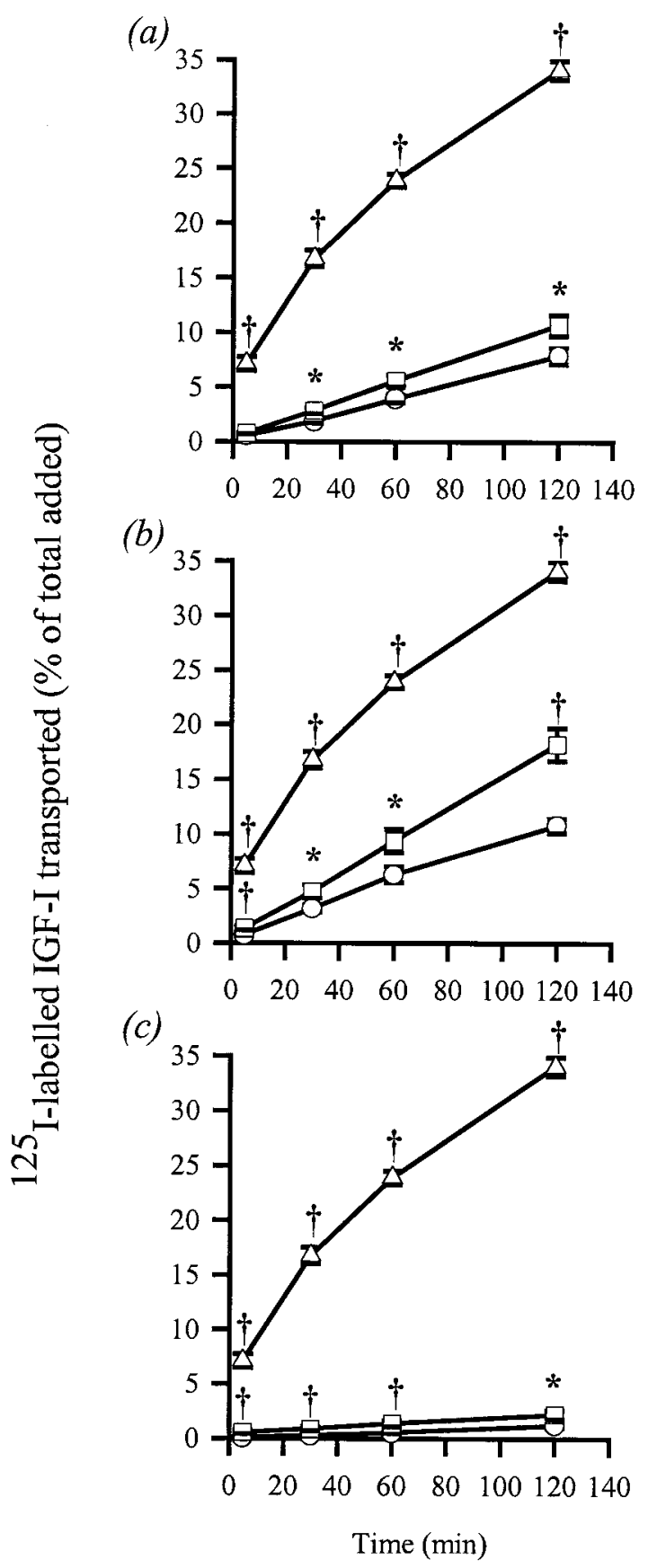

Figure 6 Transport of ${ }^{125}$ I-IGF-I $(\bigcirc)$ and $\left[{ }^{3} \mathrm{H}\right]$ inulin $(\square)$ across (a) IEC-6, (b) Mv1Lu and (c) MDBK cell monolayers. Transport of ${ }^{125}$ I-IGF-I across control transwell filters without cells is shown in each case $(\triangle)$. Transport of ${ }^{125} \mathrm{I}-\mathrm{IGF}-\mathrm{I}$ and $\left[{ }^{3} \mathrm{H}\right]$ inulin transport is expressed as a percentage of total intact ${ }^{125}$ I-IGF-I and total $\left[{ }^{3} \mathrm{H}\right]$ inulin added to the apical chamber at time zero respectively. Data are the pooled means \pm S.E.M. of triplicate transwells from six experiments. ${ }^{*} P<0 \cdot 05,+P<0 \cdot 01$ vs ${ }^{125}$ I-IGF-I across epithelial cell monolayers.
TCA-precipitable counts in the basolateral chamber of the MDBK cell cultures by the end of the $2 \mathrm{~h}$ experiment.

In order to examine whether the transport of ${ }^{125} \mathrm{I}-\mathrm{IGF}-\mathrm{I}$ is concentration dependent, a 1000-fold excess of unlabelled IGF-I was added to the apical chamber $30 \mathrm{~min}$ prior to the addition of ${ }^{125}$ I-IGF-I. As can be seen from Fig. 7, excess unlabelled IGF-I did not alter the transport of ${ }^{125}$ I-IGF-I across epithelial cell monolayers, suggesting the non-saturable flux of intact ${ }^{125}$ I-IGF-I across epithelial cell barriers.

\section{Discussion}

The major function of any epithelium is to form a selective barrier to the movement of solutes including peptides and proteins. Solute flux across an epithelial barrier can occur by either a transcellular route, involving transport systems located in the apical and basolateral membranes, or a paracellular route via intercellular spaces. The absorption of biologically active intact protein species from the intestine is well described. Thus absorption of $\left[{ }^{3} \mathrm{H}\right]-$ labelled BSA has been demonstrated in adult rats (Warshaw et al. 1974). IgG is transported from the gut lumen to the circulation by a receptor-mediated pathway in newborn calves (Jochims et al. 1994). Intestinal absorption of metabollically active insulin occurs by a transcellular pathway in rats, causing increased circulating levels of insulin followed by significant decreases in blood glucose (Bendayan et al. 1994).

Of direct relevance to the current study are several reports demonstrating intestinal absorption of intact IGF-I. It has been shown that plasma IGF-I levels increase in a dose-dependent fashion in calves orally administered IGF-I (Baumrucker et al. 1992). In 1 day old calves, supraphysiological amounts of immunoreactive IGF-I or ${ }^{125}$ I-IGF-I administered into a clamped segment of the jejunum result in the appearance of trace amounts of IGF-I or ${ }^{125} \mathrm{I}-\mathrm{IGF}-\mathrm{I}$ in the mesenteric vein draining the segment (Vacher et al. 1995). Orally administered ${ }^{125} \mathrm{I}-\mathrm{IGF}-\mathrm{I}$ is absorbed by piglets and calves with some $20 \%$ of total plasma radioactivity appearing as intact ${ }^{125} \mathrm{I}-\mathrm{IGF}-\mathrm{I}$, the majority of which is associated with plasma IGF-binding proteins (IGFBPs) (Odle et al. 1996, Xu \& Wang 1996). Donovan et al. (1997) have reported that after oral administration of ${ }^{125}$ I-rhIGF-I to pigs, some $18-20 \%$ of total radioactivity in both the portal and arterial blood were intact, with absorbed ${ }^{125}$ I-rhIGF-I representing $0.205 \%$ of the total plasma pool. In rats, rhIGF-I was absorbed into the systemic circulation where it was found to be associated with high molecular mass IGFBPs (Kimura et al. 1997). Importantly, Philipps et al. (1997) have shown that metabolically active IGF-I is absorbed. Rat pups fed rat milk substitute containing rhIGF-I gained more weight, had increased brain and liver wet weight, demonstrated increased small intestine and liver protein content, and had 
(a)

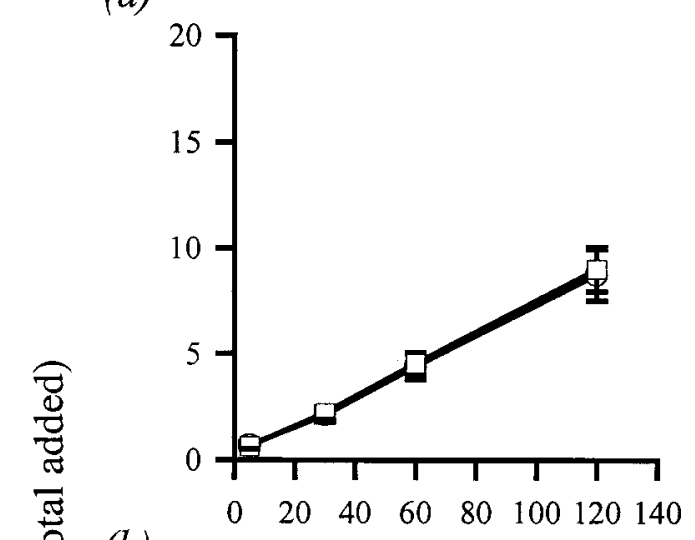

(b)

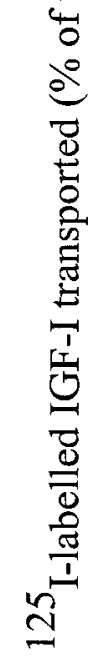

(c)
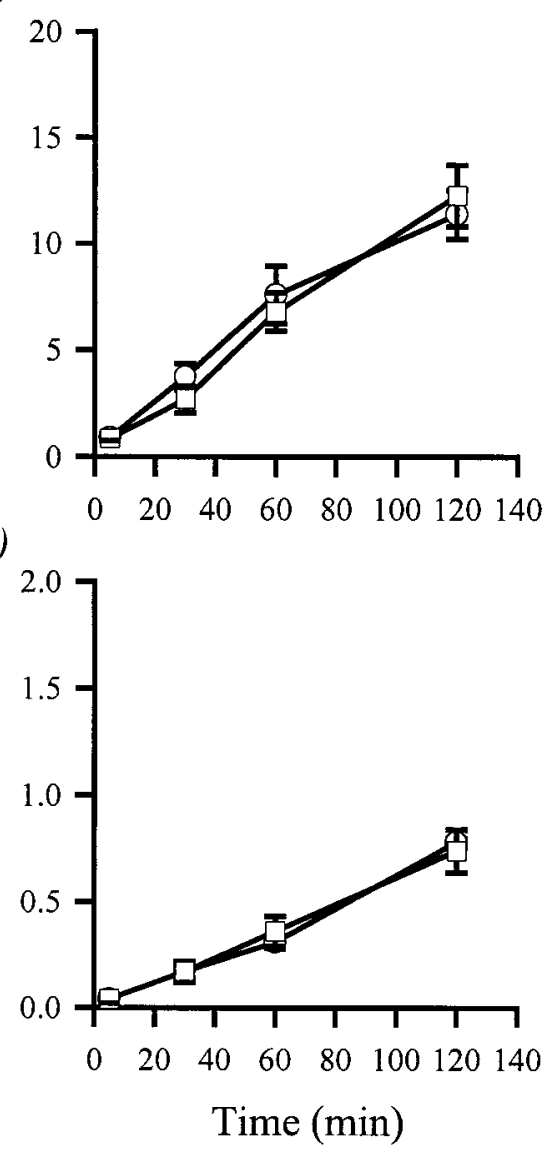

Figure 7 Effect of excess IGF-I on transport of ${ }^{125}$ I-IGF-I across epithelial cell monolayers. Transport is shown as a percentage of total intact ${ }^{125}$ I-IGF-I added to the apical chamber at time zero appearing in the basolateral chamber of (a) IEC-6, (b) Mv1Lu and (c) MDBK cultures in the presence $(\square)$ and absence $(\bigcirc)$ of a 1000 -fold excess of IGF-I. Data represent the means \pm S.E.M. of triplicate transwells from three experiments. serum IGF-I levels 2-fold those of animals fed a rat milk substitute devoid of IGF-I.

We have demonstrated the presence of functional IGF receptors on IEC-6 and Mv1Lu cells by radioreceptor, affinity label cross-linking and $\left[{ }^{3} \mathrm{H}\right]$ thymidine incorporation studies. The increased sensitivity of $\mathrm{Mv} 1 \mathrm{Lu}$ cells to IGF-I in the latter study may reflect the production or secretion of lower levels of IGFBPs compared with those of the other cell lines. Our results confirm earlier data indicating that IEC-6 cells possess type I IGF receptors (Martin \& Baxter 1992, Simmons et al. 1995). Interestingly, our finding that MDBK cells possess type I IGF receptors using radioligand binding and DNA synthesis assays could not be extended to cross-linking experiments, possibly reflecting the radioligand cell-binding kinetics over the time course of the study. In this regard, receptors for IGF-I and IGF-II have been identified on cultured canine and opossum proximal tubule cells (Hammerman \& Rogers 1987, Fawcett \& Rabkin 1995). While the type II IGF receptors were shown to be equally distributed on the basolateral and brush border membranes, the distribution of the type I IGF receptor was asymmetrical, with the basolateral membrane exhibiting a several-fold higher specific-binding capacity (Hammerman \& Rogers 1987). As MDBK cells display properties of proximal tubule cells, it may be that the radioligand is unable to access basolateral surface receptors over the time course of the cross-linking experiments. The binding of ${ }^{125}$ I-IGF-I to the surface of these cells by a competitive mechanism may reflect binding to a cell-surface binding protein. Indeed, a band at $21 \mathrm{kDa}$ was observed when cross-linked ${ }^{125}$ I-IGF-I was run out on a $12 \%$ polyacrylamide gel.

Cells cultured on a supporting microporous membrane that permits separation of the apical and basolateral solutions provide a useful model to investigate the mechanisms of solute transport across cell monolayers. In the present study, epithelial cell monolayers were maintained in serum-free conditions to minimise potential interference of serum-derived IGFs or IGFBPs. The presence of confluent cell monolayers was checked using light and electron microscopy as well as transepithelial electrical resistance measurements. Under these conditions the epithelial cell monolayers produce tight junctions. The electrical resistance measured across MDBK cells in the present studies was much higher than that of Mv1Lu and IEC-6 cell monolayers, but comparable with the value of $83 \cdot 4 \pm 15 \cdot 8 \Omega \mathrm{cm}^{2}$ cited in Cereijido et al. (1978). In addition, the MDBK cells virtually excluded any passage of ${ }^{125} \mathrm{I}-\mathrm{IGF}-\mathrm{I}$ or $\left[{ }^{3} \mathrm{H}\right]$ inulin. MDBK cells are derived from proximal tubule cells, which are not involved in protein transport but are the site of re-absorption of amino acids originating from the small amount of protein present in the glomerular filtrate. Our results thus reflect the role of these cells in vivo. The IEC-6 and Mv1Lu cell lines produced low transepithelial electrical resistance values, yet still greatly restricted the passage of ${ }^{125} \mathrm{I}-\mathrm{IGF}-\mathrm{I}$ or $\left[{ }^{3} \mathrm{H}\right]$ inulin 
compared with filters without cells. In contrast, previous studies have shown $\mathrm{T}_{84}$ colonic carcinoma cells generate high electrical resistance values, while greatly impeding the movement of electrolytes as well as macromolecules such as insulin, inulin and albumin (Milton \& Knutson 1990), and thus display characteristics more comparable with the kidney-derived MDBK line than with the gut-derived line in the current experiments. This observation possibly reflects the role of colonic epithelium as the site of water rather than protein absorption. IEC-6 and Mv1Lu cells exhibit similar characteristics to endothelial cells, which produce tight junctions and low transcellular resistance, although significantly impede the transport of macromolecules (Milton \& Knutson 1990, Bastian et al. 1997). We have recently shown that the movement of ${ }^{125}$ I-IGF-I across human umbilical vein endothelial cells occurs by restricted paracellular diffusion (Bastian et al. 1997).

The majority of ${ }^{125}$ I-IGF-I that bound to each of the three epithelial cell monolayers was almost totally displaced by relative concentrations of unlabelled IGF-I (Fig. 1) which were 10-fold less than the concentration of excess unlabelled IGF-I used in the transmigration experiments (Fig. 7). The transport of ${ }^{125}$ I-IGF-I across epithelial cell monolayers was unaltered in the presence of this excess concentration of IGF-I, suggesting a non-saturable transport mechanism. We interpret these results as demonstrating that ${ }^{125}$ I-IGF-I crosses IEC-6, Mv1Lu and MDBK epithelial cell barriers via a paracelluar or lowaffinity transcellular route, and not by a receptor-mediated pathway. Indeed, as ${ }^{125}$ I-IGF-I transport across each epithelial cell monolayer was significantly less than inulin, ${ }^{125}$ I-IGF-I transport may have been retarded by binding to cell-surface IGF receptors or IGFBPs. Transport studies utilising epithelial cell monolayers grown in a bicameral system represent a simple model which generates information regarding IGF-I transport across a well-defined homogeneous cell population and as such are a first step in the investigation of IGF-I transport from the gut lumen. However, the overall IGF effector system at the tissue level is complex and will require future in vivo studies where all components of IGF effector systems are present.

\section{Acknowledgements}

We would like to thank Ms Anna Seamark for assistance with the transmigration assays, and Dr Marilyn Henderson for her expertise with the electron microscopy.

\section{References}

Aloe L, Calissano P \& Levi-Montalcini R 1982 Effects of oral administration of nerve growth factor and its antiserum on sympathetic ganglia of neonatal mice. Developmental Brain Research $\mathbf{4}$ 31-34.
Bastian SEP, Walton PE \& Belford DA 1997 Paracellular transport of insulin-like growth factor-I (IGF-I) across human umbilical vein endothelial cell monolayers. Journal of Cellular Physiology 170 290-298.

Baumrucker CR, Hadsell DL, Skaar TC, Campbell PG \& Blum JW 1992 Insulin-like growth factors (IGFs) and IGF-binding proteins in mammary secretions: origins and implications in neonatal physiology. In Mechanisms Regulating Lactation and Infant Nutrient Utilization, pp 285-308. Eds MF Picciano \& B Lonnerdal. New York: Wiley-Liss.

Baumrucker CR, Hadsell DL \& Blum JW 1994 Effects of dietary insulin-like growth factor I on growth and insulin-like growth factor receptors in neonatal calf intestine. Journal of Animal Science $\mathbf{7 2}$ $428-433$.

Baxter RC, Zaltsman Z \& Turtle JR 1984 Immunoreactive somatomedin-C/insulin-like growth factor I and its binding protein in human milk. Journal of Clinical Endocrinology and Metabolism $\mathbf{5 8}$ 955-959.

Bendayan M, Ziv E, Gingras D, Ben-Sasson R, Bar OH \& Kidron M 1994 Biochemical and morpho-cytochemical evidence for the intestinal absorption of insulin in control and diabetic rats. Comparison between the effectiveness of duodenal and colon mucosa. Diabetologia 37 119-126.

Burrin DG, Wester TJ, Davis TA, Amick S \& Heath JP 1996 Orally administered IGF-I increases intestinal mucosal growth in formula-fed neonatal pigs. American Journal of Physiology 270 R1085-R1091.

Cereijido M, Robbins ES, Dolan WJ, Rotunno CA \& Sabatini DD 1978 Polarised monolayers formed by epithelial cells on a permeable and translucent support. Journal of Cell Biology 77 853-880.

Corps AN \& Brown KD 1987 Stimulation of intestinal epithelial cell proliferation in culture by growth factors in human and ruminant mammary secretions. Journal of Endocrinology 113 285-290.

Donovan SM, Hintz RL, Wilson DM \& Rosenfeld RG 1991 Insulinlike growth factors I and II and their binding proteins in rat milk. Pediatric Research 29 50-55.

Donovan SM, Chao JC, Zijlstra RT \& Odle J 1997 Orally administered iodinated recombinant human insulin-like growth factor-I ( ${ }^{125} \mathrm{I}$-rhIGF-I) is poorly absorbed by the newborn piglet. Journal of Pediatric Gastroenterology and Nutrition 24 174-182.

Fawcett J \& Rabkin R 1995 The processing of insulin-like growth factor-I (IGF-I) by a cultured kidney cell line is altered by IGF-binding protein-3. Endocrinology 136 1340-1347.

Gargosky SE, Walton PE, Owens PC, Wallace JC \& Ballard FJ 1990 Insulin-like growth factor-I (IGF-I) and IGF-binding proteins both decline in the rat during late pregnancy. Journal of Endocrinology 127 383-390.

Hammerman MR \& Rogers S 1987 Distribution of IGF receptors in the plasma membrane of proximal tubular cells. American Journal of Physiology 253 F841-F847.

Heinz Erian P, Kessler U, Funk B, Gais P \& Kiess W 1991 Identification and in situ localization of the insulin-like growth factor-II/mannose-6-phosphate (IGF-II/M6P) receptor in the rat gastrointestinal tract: comparison with the IGF-I receptor. Endocrinology 129 1769-1778.

Hoeflich A, Yang Y, Kessler U, Heinz-Erian P, Kolb H \& Kiess W 1994 Human colon carcinoma cells (CaCo-2) synthesize IGF-II and express IGF-I receptors and IGF-II/M6P receptors. Molecular and Cellular Endocrinology 101 141-150.

Jochims K, Kaup FJ, Drommer W \& Pickel M 1994 An immunoelectron microscopic investigation of colostral $\operatorname{IgG}$ absorption across the intestine of newborn calves. Research in Veterinary Science 57 75-80.

Kasuga M, Van Obberghen E, Nissley SP \& Rechler MM 1981 Demonstration of two subtypes of insulin-like growth factor receptors by affinity cross-linking. Journal of Biological Chemistry 256 5305-5308 
Kelly WA 1960 Passage of insulin through the wall of the gastrointestinal tract of the infant mouse. Nature 186971.

Kiliaan AJ, Scholten G, Bijlsma PB, Dekker K \& Gruct JA 1996 Influence of forskolin and carbachol on intestinal absorption of horseradish peroxidase in the goldfish (Carassius auratus). Cell and Tissue Research 285 51-56.

Kimura T, Murakawa Y, Ohno M, Ohtani S \& Higaki K 1997 Gastrointestinal absorption of recombinant human insulin-like growth factor-I in rats. Journal of Pharmacology and Experimental Therapentics 283 611-618.

Laburthe M, Rouyer-Fessard C \& Gammeltoft S 1996 Receptors for insulin-like growth factors I and II in rat gastrointestinal epithelium. American Journal of Physiology 254 G457-G462.

Laemmli UK 1970 Cleavage of structural proteins during the assembly of the head of bacteriophage. Nature 227 680-685.

LeRoith D, Werner H, Beitner Johnson D \& Roberts CT Jr 1995 Molecular and cellular aspects of the insulin-like growth factor I receptor. Endocrine Reviews 16 143-163.

Martin JL \& Baxter RC 1992 Inhibition of human fibroblast insulin-like growth factor binding protein (IGFBP) production by IGFBP-3. Endocrinology 131 1568-1570.

Milton SG \& Knutson VP 1990 Comparison of the function of the tight junctions of endothelial cells and epithelial cells in regulating the movement of electrolytes and macromolecules across the cell monolayer. Journal of Cellular Physiology 144 498-504.

Morgan CJ, Coutts AGP, McFadyen MC, King TP \& Kelly D 1996 Characterization of IGF-I receptors in the porcine small intestine during postnatal development. Journal of Nutritional Biochemistry 7 339-347.

Odle J, Zijlstra RT \& Donovan SM 1996 Intestinal effects of milkborne growth factors in neonates of agricultural importance. Journal of Animal Science 74 2509-2522.

Olanrewaju HA, Sanzenbacher ED \& Seidel ER 1996 Insulin-like growth factor I in suckling rat gastric contents. Digestive Diseases and Sciences 41 1392-1397.

Park JH, Vanderhoof JA, Blackwood D \& MacDonald RG 1990 Characterization of type I and type II insulin-like growth factor receptors in an intestinal epithelial cell line. Endocrinology 126 2998-3005

Philipps AF, Rao R, McCracken D \& Koldovsky O 1990 Presence of insulin-like growth factor: (IGF-I) in rat milk and the absorption of IGF-I by the suckling rat. Pediatric Research 27 49A.

Philipps AF, Anderson GC, Dvorak B, Williams CS, Lake M, Lebouton AV \& Koldovsky O 1997 Growth of artificially fed infant rats: effect of supplementation with insulin-like growth factor I. American Journal of Physiology 272 R1532-R1539.

Pillion DJ, Haskell JF, Atchinson JA, Ganpathy V \& Leibach FH 1989 Receptors for IGF-I, but not for IGF-II, on proximal colon epithelial cell apical membranes. American Journal of Physiology 257 E27-E34.

Read LC, Tomas FM, Howarth GS, Martin AA, Edson KJ, Gillespie CM, Owens PC \& Ballard FJ 1992 Insulin-like growth factor-I and its N-terminal modified analogues induce marked gut growth in dexamethasone-treated rats. Journal of Endocrinology 133 421-431.

Rhodes RS \& Karnovsky MJ 1971 Loss of macromolecular barrier function associated with surgical trauma to the intestine. Laboratory Investigation 25 220-229.

Ross M, Francis GL, Szabo L, Wallace JC \& Ballard FJ 1989 Insulin-like growth factor (IGF)-binding proteins inhibit the biological activities of IGF-I and IGF-2 but not des-(1-3) IGF-I. Biochemistry Journal 258 267-272.

Rouyer Fessard C, Gammeltoft S \& Laburthe M 1990 Expression of two types of receptor for insulin-like growth factors in human colonic epithelium. Gastroenterology 98 703-707.

Ryan J \& Costigan DC 1993 Determination of the histological distribution of insulin-like growth factor 1 receptors in the rat gut. Gut 34 1693-1697.

Schober DA, Simmen FA, Hadsell DL \& Baumrucker CR 1990 Perinatal expression of type I IGF receptors in porcine small intestine. Endocrinology 126 1125-1132.

Simmons JG, Hoyt EC, Westwick JK, Brenner DA, Pucilowska JB \& Lund PK 1995 Insulin-like growth factor-I and epidermal growth factor interact to regulate growth and gene expression in IEC-6 intestinal epithelial cells. Molecular Endocrinology 9 1157-1165.

Thornburg W, Matrisian L, Magun B \& Koldovsky O 1984 Gastrointestinal absorption of epidermal growth factor in suckling rats. American Journal of Physiology 246 980-985.

Vacher PY, Bestetti G \& Blum JW 1995 Insulin-like growth factor I absorption in the jejunum of neonatal calves. Biology of the Neonate 68 354-367.

Vega JR, Gibson CA, Skaar TC, Hadsell DL \& Baumrucker CR 1991 Insulin-like growth factor (IGF)-I and -II and IGF binding proteins in serum and mammary secretions during the dry period and early lactation in dairy cows. Journal of Animal Science 69 2538-2547.

Walker WA, Cornell R, Davenport LM \& Isselbacher KJ 1972 Macromolecular absorption: mechanism of horseradish peroxidase uptake and transport in the adult and neonatal rat intestine. Journal of Cell Biology 54 195-205.

Warshaw AL, Walker WA \& Isselbacher KJ 1974 Protein uptake by the intestine: evidence for absorption of intact macromolecules. Gastroenterology 66 987-992.

Wheeler EE, Challacombe DN, Kerry PJ \& Pearson EC 1993 A morphological study of beta-lactoglobulin absorption by cultured explants of the human duodenal mucosa using immunocytochemical and cytochemical techniques. Journal of Pediatric Gastroenterology and Nutrition 16 157-164.

Xu RJ \& Wang T 1996 Gastrointestinal absorption of insulin-like growth factor-I in neonatal pigs. Journal of Pediatric Gastroenterology and Nutrition 23 430-437.

Received 30 November 1998

Accepted 9 April 1999 